\title{
COMMENT
}

\section{THE INVERSE COASE THEOREM AND DECLARATIONS OF WAR}

\section{J. Gregory SiDAK*}

Relying on constitutional text, history, and the theorem for which Ronald Coase won the Nobel Prize, ${ }^{1}$ I argued in this Journal that Congress should formally declare war when authorizing the use of military force on the scale of the Persian Gulf War. ${ }^{2}$ Professor Harold Hongju Koh of the Yale Law School rephed that my "ill-advised ambition to marry constitutional originalism with law-and-economics should be killed before it spreads."3 Although flattered to play Salman Rushdie to Koh's Ayatollali, I suggest that the professor call off the jihad.

I agree that "the Constitution no more enacts the Coase Theorem than it does Herbert Spencer's Social Statics." 4 That does not mean, however, that economics cannot illuminate the compelling logic of the Framers' desigu. Far from arguing that the Framers "enacted" as a matter of original intent what we now call the Coase Theorem, I offered a normative interpretation of the War Clause that built upon a positive economic analysis of the separation of powers.

Coase observed that in the absence of transaction costs, the ultimate use of a resource will be determined not by the initial assignment of property rights between two parties, but rather by which of the two parties can put the resource to its highest-valued use, and thus will have the ineans and incentive to induce the other party to exchange his rights to that resource. Normatively, the Coase Theorem implies that legal rules

- A.B. 1977, A.M., J.D. 1981, Stanford University. Member of the California and District of Columbia Bars. I thank Fred S. McChesney, Geoffrey P. Miller, Richard A. Posner, Melinda Ledden Sidak, Thomas A. Smith, and Matthew L. Spitzer, who were kind enough to read this paper in draft. The views expressed here are solely my own.

1. See Ronald H. Coase, The Problem of Social Cost, 3 J.L. \& Econ. 1 (1960).

2. See J. Gregory Sidak, To Declare War, 41 DUKE L.J. 27 (1991).

3. Harold H. Koh, The Coase Theorem and the War Power: A Response, 41 DUKE L.J. 122, 125 (1991).

4. Id. at 128-29. 
should facilitate such bargaining by reducing transaction costs. ${ }^{5}$ However, as James Buchanan has argued, when the Theorein is extended to a theory of the state, "new and previously nonexistent 'rights of decision' are brought into being, rights that have economic value that is potentially capturable by the subset of the citizenry einpowered to inake decisions on behalf of all."6 Monitoring the officials who exercise rights of decision is costly. The diverse output of government is not amenable to expression in a few statistics (as are the profitability and risk of a public corporation, for example), and, as presentinent shows, many government decisions are joint products of several agents in separate branches-a distribution of responsibilities that nivites shirking. ${ }^{7}$

Monitoring costs are reduced, and political accountability enhanced, by prohibiting bargams that alter the Constitution's forinal allocation of rights of decision among political actors. ${ }^{8}$ One might describe this proposition as the "Inverse Coase Theorein." Koh apparently has misunderstood my basic point; he claims that constitutional controversies cannot satisfy the Coase Theoreni's underlying assumptions. ${ }^{9}$ If ouly this were true, I would be the last to complaim. It would be desirable if an absence of necessary conditions im addition to zero transaction costs thwarted the reallocation of rights of decision. ${ }^{10}$ But obviously the executive and legislative branches do make bargams that reallocate constitutional rights of

5. See Robert COOTER \& Thomas Ulen, LAW AND Economics 101 (1988); Robert Cooter, The Cost of Coase, 11 J. Legal Stud. 1, 14-20 (1982).

6. JAMES M. BUChANAN, EXPLORATIONS INTO CONSTITUTIONAL EConomics 397 (Robert D. Tollison \& Viktor J. Vanberg eds., 1989).

7. See Armen A. Alchian \& Harold Demsetz, Production, Information Costs, and Economic Organization, 62 AM. Econ. REv. 777, 779-81 (1972); Morris Fiorina, Group Concentration and the Delegation of Legislative Authority, in Regulatory POLiCY AND the Social Sciences 175, 179 (Roger Noll ed., 1985).

8. Such rights are inalienable so that their holder may not "sell them or ... exploit his possession of them through collection of personal rewards, either directly or indirectly," and this inalienability "clearly makes the [Coase] theorem of allocational neutrality invalid." BUCHANAN, supra note 6 , at 398.

9. See Koh, supra note 3, at 129.

10. Only if I were arguing that bargains between the branches should occur would I need to ask when they can occur. See id. at 129-30 nn.39 \& 40 (citing Elizabeth Hoffman \& Matthew L. Spitzer, The Coase Theorem: Some Experimental Tests, 25 J.L. \& EcoN. 73 (1982); Elizabeth Hoffman \& Matthew L. Spitzer, Experimental Tests of the Coase Theorem with Large Bargaining Groups, $15 \mathrm{~J}$. LEGAL STUd. 149 (1986)).

Koh also states that "analogizing constitutional powers to 'property rights' oversimplifies to the poimt of distortion" because "separation of powers principles do not draw sharp boundaries between congressional and presidential authorities in foreign affairs." Koh, supra note 3, at 130 . One could say the same about the use of the air by one party to dry laundry and by another to dispose of sooty exhaust. Why should it be harder to define the war powers (and duties) of the President and Congress than to define property rights im the electromagnetic spectrum (which Coase was studying when he had the insight for The Problem of Social Cost, see Coase, supra note 1, at $1 \mathrm{n} .1$ (discussing Ronald H. Coase, The Federal Communications Commission, 2 J.L. \& Econ. 1 (1959)))? For a more 
decision. Curiously, after Koh says that this practice is impossible, he lauds the occasions where it does happen-an interesting position in that it is both empirically false and logically self-contradictory. ${ }^{11}$ Koh's hypothetical, im which the President's trespassing cattle damage Congress's crops, also shows how he has missed my poimt. ${ }^{12}$ My point is that there are agency costs associated with some kinds of cooperative behavior between the branches. If the President (ranch manager) and the Congress (farm manager) were mutually to agree to share something that belonged to the People (landowner), then the hypothetical would be relevant. In the Persian Gulf War, Congress and the President mutually agreed to ignore the constitutionally required formality of declaring war when in fact mitiating full-scale offensive war, all to the detriment of the principal- "We the People" - of whom both the President and Congress are supposed to be agents.

If the branches do trade rights of decision, it becomes more difficult for a citizen to know which branch is responsible for a particular decision. He therefore mcurs higher cost in petitioning government. Moreover, the locus of a decision can alter the decision itself. Such factors as the different discount rates for assessing pohicy options implied by the

critical analysis of the limits of analogizing the separation of powers to property rights, see Geoffrey P. Miller, Rights and Structure in Constitutional Theory, 8 Soc. PHIL. \& PoL'y 196, 201-05 (1991).

11. Koh asserts: "To argue that Congress may only approve war by formal declaration makes about as much sense these days as a claim the Congress may only approve an international commitment by a treaty ratified by two-thirds of the Senate," because an executive agreement approved by joimt resolution "has become viewed as effectively interchangeable with an Article II treaty for forging our international commitments." Koh, supra note 3, at 126 \& n.24. Far from supporting Koh's position, this example demonstrates why the inalienability of rights of decision matters.

Calling a treaty a congressional-executive agreement could produce a different decision-either because it would disable one-third plus one members of the Senate froin vetoing a treaty, or because Congress may usurp the President's control of the agenda in the treaty-making process by negotiating a treaty and then overriding the President's veto of the joint resolution enacting it as an international agrecinent.

With respect to the second possibility, although a congressional-executive agrecment supposedly "can be concluded only by the President, who alone possesses the constitutional power to negotiate with other governments," that rule is violated if the agreement can substitute for a treaty "in every instance." RESTATEMENT (THIRD) OF THE FOREIGN RELATIONS LAW OF THE UNITED STATES $\$ 303$ cint. e (1987) (emphasis added). In 1987, for example, Speaker of the House Jim Wright discussed arms reductions directly with Mikhail Gorbachev. See J. Gregory Sidak, The President's Power of the Purse, 1989 DUkE L.J. 1162, 1212; see also Statement on Signing the Departments of Commerce, Justice, and State, the Judiciary, and Related Agencies Appropriations Act, 1992, 27 WEekLy CoMP. PRES. Doc. 1529 (Oct. 28, 1991) ("The Constitution . . . vests exclusive authority in the President to control the timing and substance of negotiations with foreign governments and to choose the officials who will negotiate on behalf of the United States.").

Rather than cxplain why we shonld no longer care about the President's control over treaties and the prerogative of a minority of the Senate to veto them, Koh cites the Necessary and Proper Clause, U.S. CoNST. art. I, $\S 8$, cl. 18 , as if it empowers Congress to strike outmoded words from the Constitution. See Koh, supra note 3, at 126-27.

12. See Koh, supra note 3 , at 131. 
differing tenure of judges, senators, presidents, and representatives; the different constituencies represented through different modes of election for each branch (and each house of Congress); the different degrees to which vote cycling is implied by the different methods of agenda control in the three branches; and the influence on the speed and secrecy of decisions caused by the relative unity or plurality of the decision process, can all affect the content of a particular decision.

Nonetheless, Koh views the phrase "To declare War" as outmoded. Although the United States and its allies killed as many as 150,000 Iraqi soldiers during the six-week Persian Gulf War, ${ }^{13}$ Koh calls it "nothing less than bizarre" and an instance of "mindless originalism" to insist that lethal force of such magintude inust be authorized by the declaration of war for which the Constitution expressly provides. ${ }^{14}$ He urges that "formal declarations of war [be] left to their special historical place."15 Whiat that place is, and how killing 25,000 persons per week is an illustration of Congress using the "scalpel" of a limited authorization of war rather than the "meat cleaver" of a forinal declaration of war, ${ }^{16}$ are questions that Koh does not attempt to answer.

13. See Caryle Murphy, Iraqi Death Toll Remains Clouded, WASH. PoST, June 23, 1991, at A1, A17 (reporting Defense Intelligence Agency estimates).

14. See Koh, supra note 3 , at $127,128$.

15. Id. at 132 .

16. See id. at 128. 